\title{
EEG Analysis of Human exposed to interior noise of KTX and Saemaul-ho $\mathrm{KTX}$ 와 새마을호의 실내소음에 노출된 인간의 뇌파 분석
}

\author{
S. A. Ryu*, Y. S. Jang**† and K. C. Park*

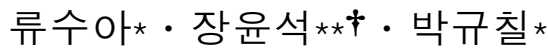

(received 03 May 2012, revised 27 July 2012, accepted 07 August 2012)

주요용어 : 뇌파(EEG), 상대베타파워(relative $\beta$ power), 내부소음(interior noises), FFT(Fast Fourier Transform)

요 약 : 오늘날 고속 철도는 중요한 교통수단으로 사용되고 있다. 주행거리 단축을 위해 직선 선로를 만드 는 것이 불가피해 졌고 그에 따라 터널과 교량의 구간이 늘어나게 되었다. 특히 터널 통과 시에 발생되는 실내 소음은 운행 속도, 운행 구간 레일의 종류 등 여러 가지 원인에 의해 야기되어 진다. 실내소음으로 인 해 철도를 이용하는 승객의 쾌적한 환경에 많은 영향을 미치게 된다. 이에 본 연구에서는 KTX와 새마을호 의 터널 통과 시 발생되는 소음이 피험자에게 미치는 영향을 $\mathrm{EEG}$ 를 통해 살펴보았다. 먼저 터널 통과 시 $\mathrm{KTX}$ 와 새마을호의 실내 소음을 실제로 측정하여 크기, 주파수별로 분석하였다. 측정된 실내 소음을 피험자 에게 제시하였을 때 나타나는 $\mathrm{EEG}$ 를 측정하였다. $\mathrm{EEG}$ 의 분석에 대해서는 불안, 긴장 등 스트레스를 받을 때 강하게 나타나는 $\beta$ 파의 변화를 관찰한 결과를 제시하였다.

\section{Introduction}

Recently, there have been many advances in the railroad industry. Because the railroad industry became a high-tech industry to combine the most advanced technologies. Especially, the investment for speeding up of conventional railroads made a great accomplishment.

High-speed train, named KTX(Korea Train Express), was introduced to Korea and the transportation service started from 2004. The Gyeongbu line among the KTX lines is connected between Seoul and Busan and is the major means of transportation in Korea. The travel time between Seoul and Busan was reduced from 2 hours 40 minutes to 2 hours 18 minutes because of complete opening of Busan-Daegu section for KTX in 2010. To increase running speed and

**† 장윤석(교신저자) : 부경대학교 전기공학과

E-mail : jangys@pknu.ac.kr, Tel : 051-629-6319

*류수아 : 부경대학교 정보통신공학과

*박규칠 : 부경대학교 정보통신공학과 straight section, the number of tunnels was increased. The interior noises of the high-speed trains are generated by several reasons. There have been many researches of the interior noise for high-speed train by types of railroad, speed of train, driving conditions and degree of noises ${ }^{1 \sim 3)}$. The degree of noises have been analyzed by various quantitative methods. The interior noises had influences on passengers' comfort when they use the trains. Ultimately, it is necessary to study the influence of the passengers by the interior noises.

According to precedent study, interior noises in the KTX and the Saemaul-ho were different in loudness level and frequency distribution ${ }^{4 \sim 5}$. Different interior noise characteristics can make different external stimulus. EEG (Electroence phalography) might be changeable by the different

$* * \dagger$ Y. S. Jang(Corresponding author) : Department of Electrical Engineering, Pukyong National University.

E-mail : jangys@pknu.ac.kr, Tel : 051-629-6319

*S. A. Ryu, K. C. Park : Department of Information and Communications Engineering, Pukyong National University. 
external stimulus. Therefore, in our experiments, we used with stimuli to subjects the interior noises of the KTX and the Saemaul-ho when they passed through tunnels. At that time, we measured and analyzed the EEG due to the interior noises.

Human brain activity have been estimated with measurement and analysis of the EEG. The EEG frequency bands is useful for the estimation to be categorized as delta $(1$ to $4 \mathrm{~Hz})$, theta $(4$ to $8 \mathrm{~Hz})$, alpha( 8 to $13 \mathrm{~Hz})$ and $\operatorname{beta}(13$ to $30 \mathrm{~Hz})$. It was reported that the power of the $\beta$ band reflected to disquietude, receiving tension and stress $^{6 \sim 7}$ ).

Therefore, we carried out the experiments to measure the EEG of the subjects when the interior noises of the KTX and the Saemaul-ho were presented with stimuli and analyzed the variation of the $\beta$ waves in the EEG. Finally, we presented the experimental results that the variation of the $\beta$ waves could be related with the degree of stress.

\section{Experimental procedure and method}

\subsection{Analysis of interior noises}

It takes $48 \%$ of the total running time to go through tunnels in Busan - Daegu section of the KTX. The interior noises of the KTX was measured $70 \mathrm{~dB}$ in open area(normal railroad), $80 \mathrm{~dB}$ in tunnel. In case of the Saemaul-ho, it was measured about $60 \mathrm{~dB}$ in open area, about $70 \mathrm{~dB}$ in tunnel. The case of the KTX was about $10 \mathrm{~dB}$ higher than that of the Saemaul-ho. According to these results, we know that the loudness levels of the interior noises were different in each cases. We also analyzed the interior noises in frequency domain. Fig. 1 shows the frequency spectra in $1 / 3$ octave band. The results in frequency domain represents that the component of lower $250 \mathrm{~Hz}$ affected the total noises. It was generally known that the frequency band below $250 \mathrm{~Hz}$ have relatively low transmission loss in case of a vehicle $^{8)}$.

In the KTX, there were distinct differences at $250 \mathrm{~Hz}$ and $400 \mathrm{~Hz}$. In the Saemaul-ho, there were distinct differences at $400 \mathrm{~Hz}$ and $4000 \mathrm{~Hz}$. We detected peak frequencies in lower $2 \mathrm{kHz}$ when the trains passed through a tunnel using the method of sector space averaging ${ }^{9)}$.

$$
y[n]=x[n]-\frac{1}{2 N} \sum_{k=1}^{N}\{x[n-k]+x[n+k]\}
$$
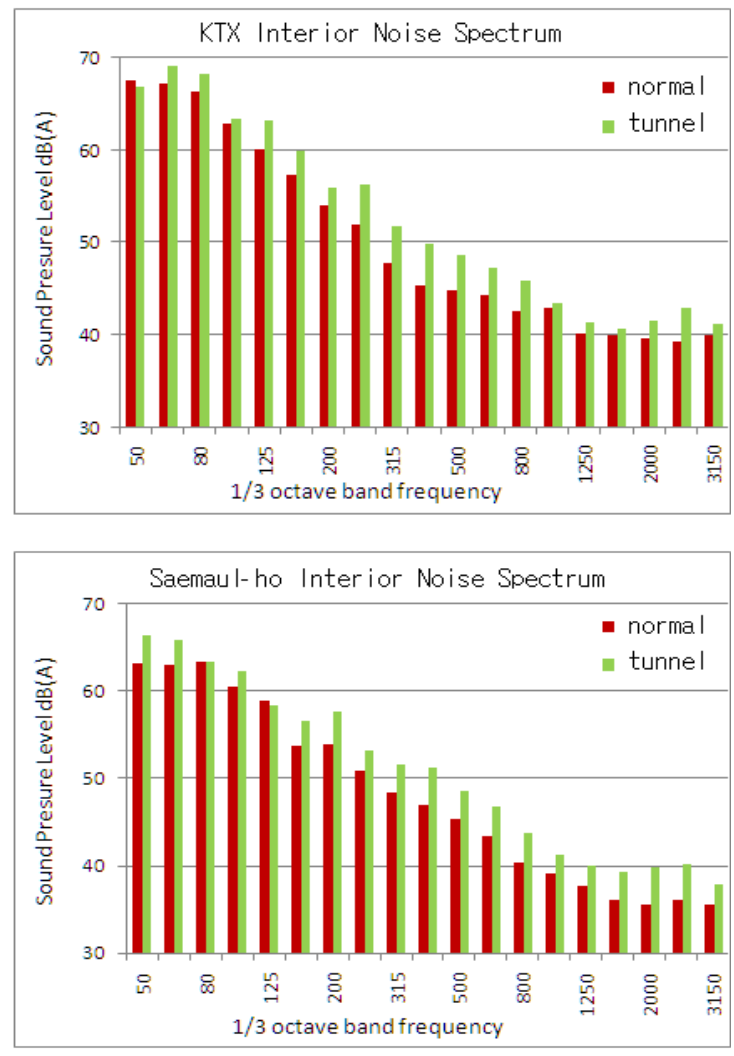

Fig. 1 Interior noises spectrum
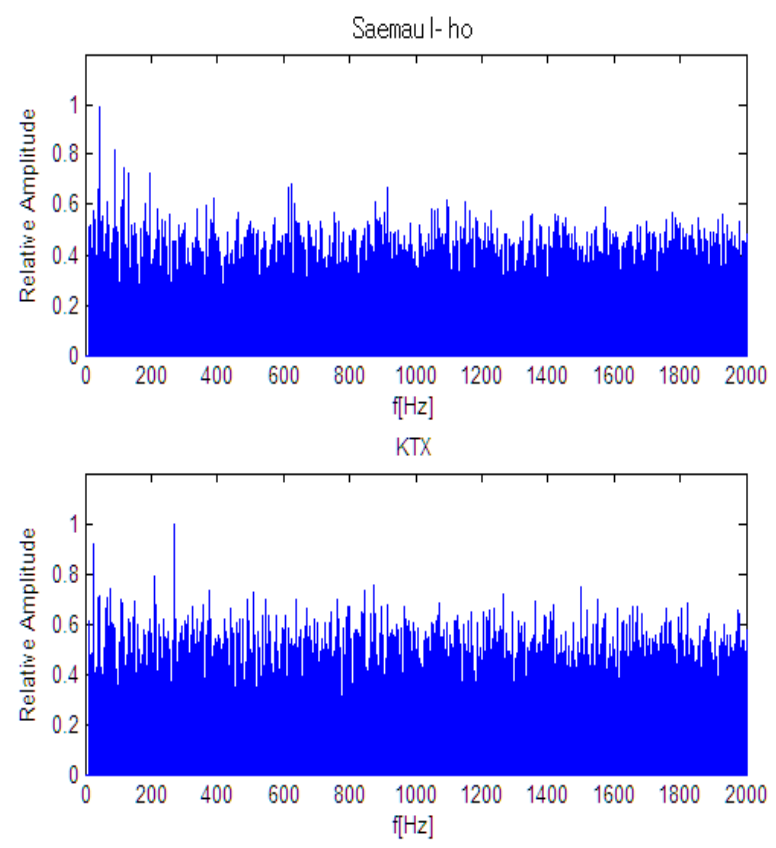

Fig. 2 Peak frequency through tunnels 
Fig. 2 shows the peak frequencies of the KTX and the Saemaul-ho respectively. In the Saemaul-ho, there were high peaks at $50 \mathrm{~Hz}$ and $90 \mathrm{~Hz}$. In the KTX, there were high peaks at $25 \mathrm{~Hz}$, $200 \mathrm{~Hz}$ and $270 \mathrm{~Hz}$. From those results, we are able to assume that the interior noises of the KTX and the Saemaul-ho are caused by the different reasons. We used the interior noises to be analyzed above for our EEG experiments.

\subsection{Experimental Methods}

The measurement system called PolyG-A by Laxtha was used for recording EEG. The EEG activity was recorded at F3, Fz, F4, C3, Cz, C4, $\mathrm{P} 3, \mathrm{Pz}$ and $\mathrm{P} 4$ according to the extended international $10-20$ system $^{10)}$. The sampling rate was selected to $256 \mathrm{~Hz}$. The channel data were produced by monopolar derivation. Subjects were 5 male university students and all subjects reported being free of neurological or psychiatric disorders. Their ages were from 23 to 25 . Our experiments were progressed in open eyes for preventing drowsiness.

The stimuli to present were recorded the interior noises when the trains were passing through tunnels, and the noise levels were set by 80dB(KTX) and 70dB(Saemaul-ho), equal to actual level. The interval between the stimuli was separated by the state without noises. Meditation music was presented during the state without noises.

The MM state in Fig. 3 means that subjects are listening to the meditation music. It is to stabilize the EEG and intended to minimize the effect of prior stimulus. To avoid rapid changes of the sound level, we applied fade-in and fade-out to the beginning and the end of the stimulus and the meditation music. The procedure of our EEG experiment is shown in Fig. 4.

\section{Experimental results and discussion}

EEG is classified into delta wave, theta wave, alpha wave and beta wave in frequency band.

\begin{tabular}{|c|c|c|c|}
\hline 1 min & 3min & $\operatorname{1min}$ & 3min \\
& $\begin{array}{c}\text { Stimulus } \\
\text { (KTX) }\end{array}$ & $\begin{array}{c}\text { MM } \\
\text { state }\end{array}$ & $\begin{array}{c}\text { St imulus } \\
\text { (Saemaul-ho) }\end{array}$ \\
\hline state
\end{tabular}

Fig. 3 Stimulus presentation method

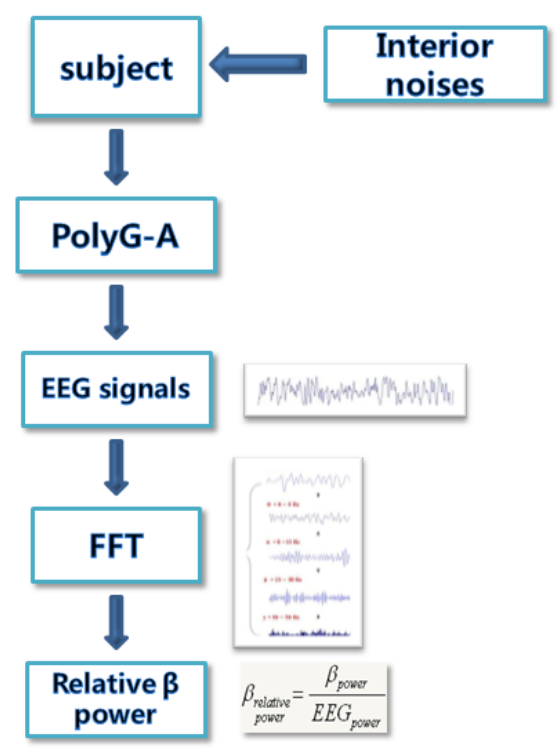

Fig. 4 A schematic diagram of EEG experiment

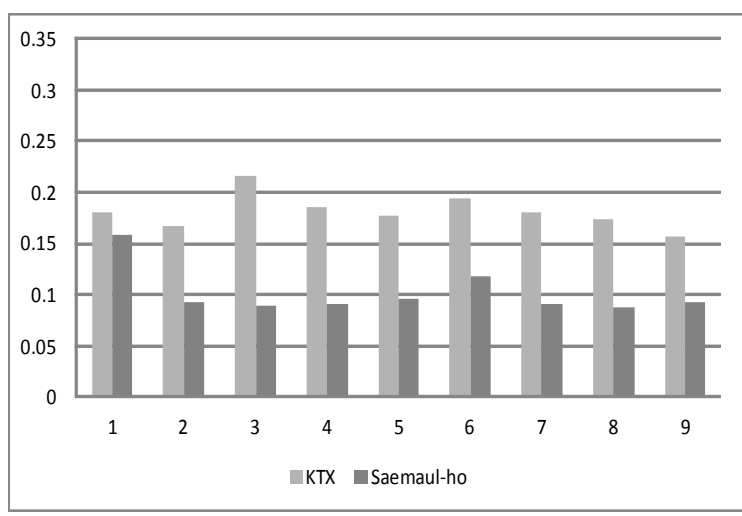

(a) Subject 1

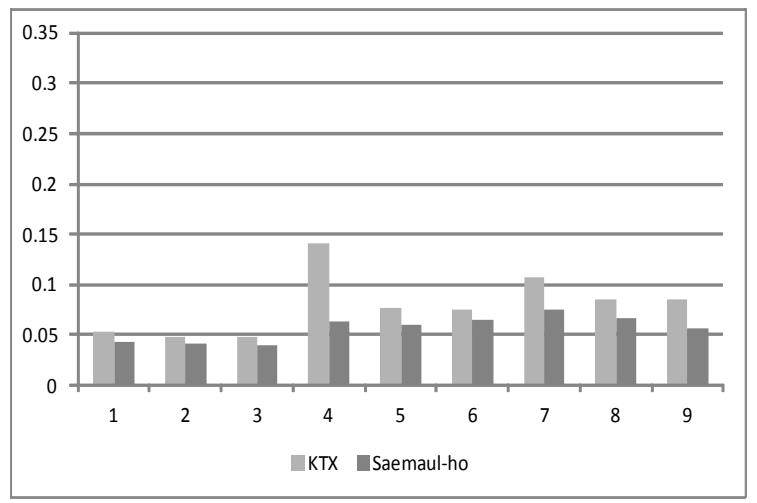

(b) Subject 2 


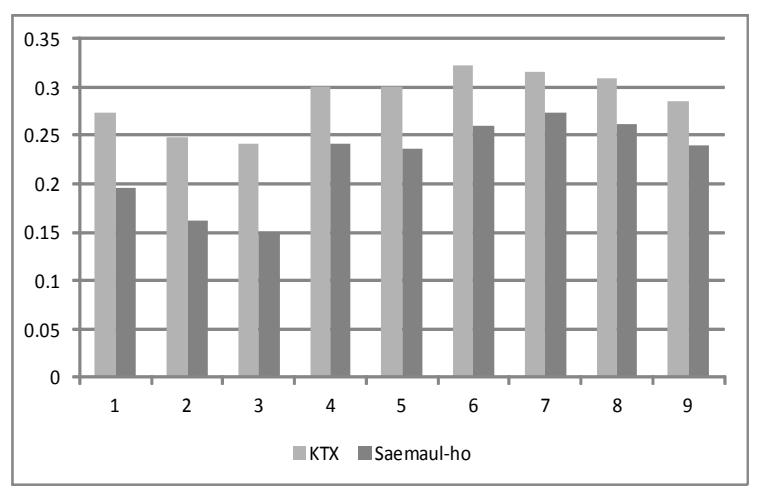

(c) Subject 3

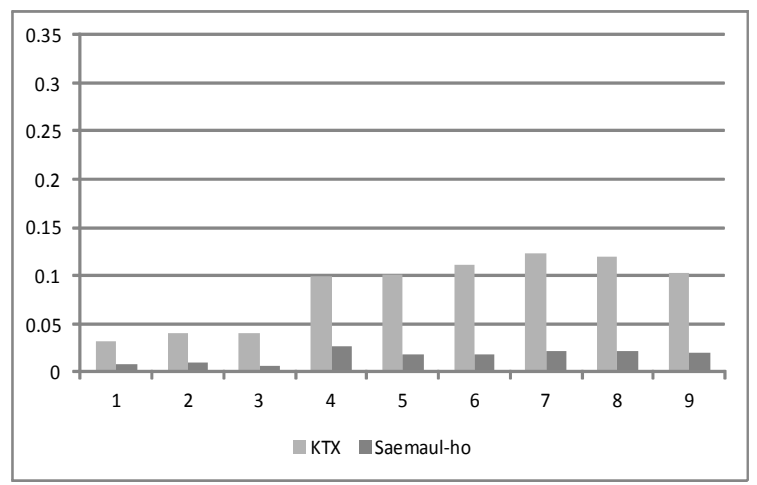

(d) Subject 4

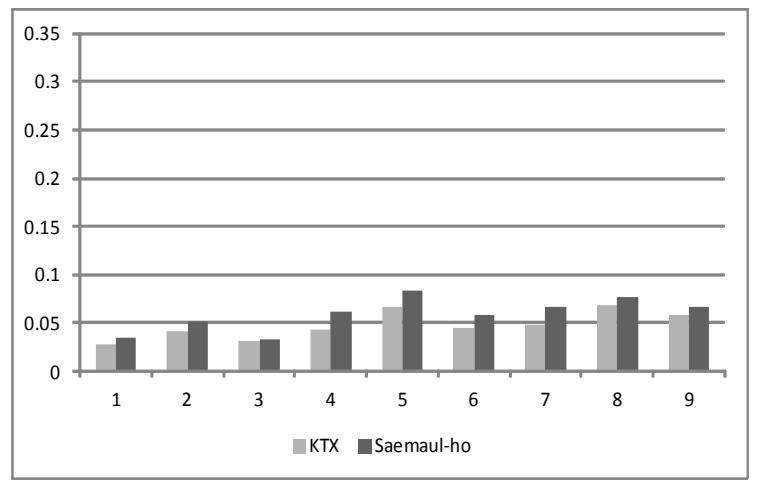

(e) Subject 5

Fig. 5 The relative $\beta$ power of subjects according to the channel

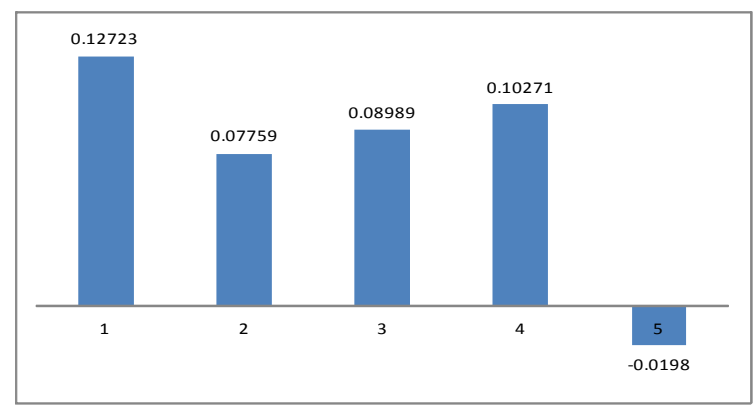

Fig. 6 The differences of the relative $\beta$ power between the KTX and the Saemaul-ho
The spectrum of the EEG is computed using Fast Fourier Transform (FFT). Then the $\beta$ relative power is calculated as the ratio of $\beta$ band power and the whole EEG spectrum power. The $\beta$ relative power is calculated as follows:

$$
\beta_{\text {r.p. }}=\frac{\beta_{\text {power }}}{E E G_{\text {power }}}
$$

Fig. 5 shows the relative $\beta$ power of 5 subjects to calculate at each channels when the stimuli of the interior noises were presented. Four subjects have the larger relative $\beta$ power of the interior noises by the KTX than that of the Saemaul-ho. One subject only has the large relative $\beta$ power of the interior noises by the Saemaul-ho.

Fig. 6 shows the differences of the relative $\beta$ power between the KTX and the Saemaul-ho. The upper direction of the horizontal axis represents the large $\beta$ power of the KTX and the lower direction of the horizontal axis represents the large $\beta$ power of the Saemaul-ho. The difference values of the relative $\beta$ power for four subjects are $0.12723, \quad 0.07759, \quad 0.08989$ and 0.10271. The difference value of the relative $\beta$ power due to the interior noises of the Saemaul-ho is -0.0198 .

In our experiment results, it can be shown clearly that the relative $\beta$ power of EEG due to the KTX is large at the most. In the larger relative $\beta$ power due to the interior noises by the Saemaul-ho, the difference of the relative $\beta$ power is very small.

\section{Conclusions}

In this study, we analyzed the interior noises of the KTX and the Saemaul-ho. The results showed that the interior noises in the KTX and the Saemaul-ho were different in loudness level and frequency spectrum. The interior noises of the KTX was about $10 \mathrm{~dB}$ higher than that of the Saemaul-ho. In the KTX, there were distinct differences at $250 \mathrm{~Hz}$ and $400 \mathrm{~Hz}$. In the Saemaul-ho, there were distinct difference at $400 \mathrm{~Hz}$ and $4000 \mathrm{~Hz}$. These results show that how 
much is the difference of the interior noises between the KTX and the Saemaul-ho and the interior noises of each train are caused by the different reasons. The studies of positive and negative effect with the EEG spectrum have been studied by M. C. Whang et al(1997), J. Y. Kim et $\mathrm{al}(2001)$ and D. H. Kyon et $\mathrm{al}(2009)^{11 \sim 13)}$. The previous studies have found the results that the $\beta$ activity was correlated with discomfort of the subjects.

Therefore, nextly we measured the EEG signals when the interior noises by the KTX and the Saemaul-ho were presented the stimuli and calculated the relative $\beta$ power from the EEG signals. In the experimental results, $80 \%$ of subjects have the large relative $\beta$ power of the interior noises by the KTX. 20\% of subjects have the large relative $\beta$ power by Saemaul-ho, but there is a small difference between the relative $\beta$ power of the Saemaul-ho and that of the KTX. The difference value 0.0198 is $2.55 \%$ of the smallest value among the relative $\beta$ powers. This result means the case to have the similar $\beta$ power for two types of the trains. It could be assumed that most of people felt more discomfort in the KTX than in the Saemaul-ho from the relative $\beta$ powers of the experimental results.

However it is thought that the difference of the relative $\beta$ powers may be not caused from the difference of loudness level in the interior noises because one subject have the similar response for the stimuli from the two types of trains. Therefore we need to find the reasons to cause the larger $\beta$ power in the KTX based on this study. Especially considering there are many tunnels in BusanDaegu section of the KTX, it requires to find and reduce the reasons of the interior noises in the KTX for a comfortable ride.

\section{Acknowledgement}

This work was supported by the Pukyong National University Research Abroad Fund in PS-2008-0773.

\section{Reference}

1. B. Park et al., 2010, "Sound Quality Characteristics for Interior Noise of High Speed Train", Journal of KSNVE, Vol. 20, pp. 774-781.

2. H. I. Koh, J. C. Kim, and C. W. Lee, 2006 "A Study on Noise Characteristics of High Speed Trains" The Korean Society for railway Annual Spring Conference.

3. H. J. Chun, D. S. Kim, J. H. Ko and S. I. Chang, 2008, "Jury Evaluation Test for Annoyance Response of KTX and Ordinary Train Noise" Jounal of KSNVE, Vol. 18, pp, 335-344.

4. S. H. Jeun, K. C. Park, Y. S. Jang and S. A. Ryu, 2011, "Characteristics of Interior Noise of KTX”, Acoustical Society of Korea Conference.

5. J. C. KIM, and C. W. Lee. 2007, "Analysis of Interior Noise of KTX in Tunnel with Concreted Track", Journal of KSNVE, Vol. 17, No 11.

6. D. H. Moon, and Y. W. Kim, 2007, "The Effect of Stress Reduction of Human Body by the Vibroacoustic Equipment", Journal of KSPSE, Vol. 11, No.2 pp. 32-37.

7. S. K. Park et al., 2006, "The Auditory and Visual Information Impacts on the Traffic Noise Perception by using Electroencephalogram", KSNVE06A-02-04.

8. S. H. Choi, J. C. Kim, C. W. Lee and J. H. Cho, 2004, "Interior noises of KTX vehicle in a tunnel" The Korean Society for railway Annual Spring Conference, pp. 88-92.

9. Richard O. Nielsen, Sonar Signal Processing, Artech House, INIC., Boston, pp. 155 157 1991.

10. P. F. Harner and T. Sannit, "A review of the international ten-twenty system of electrode placement" Grass Instrument, 1974.

11. M. C. Whang, E. K. Ryu, E. H. Byun and C. J. Kim, 1997, " Normalized Sensitivity Using EEG as an Objective Emotional Index" Proceedings of the Korean Society for Emotion and 
Sensibility Conference, pp. 80-84.

12. J. Y. Kim and C. S. Park, 2001, "Evaluation of Car Interior Noise by Using EEG" Journal of the Society of Korea Industrial and Systems Engineering, Vol. 24, No 65, pp. 65-73.

13. D. H. Kyon and M. J. Bae, 2009, "Analysis of Acoustic Psychology of City Traffic and Nature Sounds" Journal of the Acoustical Society of Korea, Vol. 28, No 4, pp. 356-362. 